\title{
Churn Analytics on Indian Prepaid Mobile Services
}

\author{
P.S. Rajeswari \& P. Ravilochanan \\ ${ }^{1}$ School of Management, SRM University, Kattankulathur, India \\ ${ }^{2}$ Research Associate, School of Management, SRM University, Kattankulathur, India \\ Correspondence: P.S. Rajeswari, School of Management, SRM University, Kattankulathur-603 203, India. Tel: \\ 91-994-457-5575. E-mail: psrajee_2003@yahoo.co.in
}

Received: April 17, 2014 Accepted: May 16, 2014 Online Published: June 25, 2014

doi:10.5539/ass.v10n13p169 URL: http://dx.doi.org/10.5539/ass.v10n13p169

\begin{abstract}
India, the second largest in telecommunication industry facing acute rise in mobile churn. Churn rate is very high in prepaid segment when compared with postpaid in India. Even though marketers are devoting huge investments on retention campaigning they could not arrest the churn rate. Many attractive promotional schemes and packages were offered to retain the prepaid customers as the cost of acquisition is very expensive. They were all found to be ineffective since churn rate is pungently alarming every day in prepaid scenario. Hence it is highly imperative to devise proactive retention strategies by percolating the operational churn factors and to design predictive model to stem out the churn rate in India. Thus this study focuses on the factors influencing churn in prepaid segment and conceptual predictive model using neural networks to enervate customer churn.
\end{abstract}

Keywords: churn analytics, mobile operators, customer loyalty, customer retention, social media marketing, and data mining, neural networks

\section{Introduction}

The Indian telecommunications industry is one of the fastest proliferating sectors in the world. Mobile prepaid customers are vibrant in changing their mobile operators within very short span. Churn rate increases pungently in parallel to the growth of prepaid mobile subscribers. Customer churn happens to be the most challenging issue for mobile industry irrespective of its rapid growth. This in turn entangled with disloyalty and as the industry saturates it become imperative for the mobile operators to redesign service plans with new offerings to enhance customer loyalty. Customer retention, therefore, is becoming critical to sustain customer base. In this regard it is essential to investigate the basis for switching of the prepaid mobile users in India.

Silvia trif, Adrian visoiu, Romania (2013), pointed out the need for churn prediction system that addresses the working of mobile operators with the given peculiarities of the environment. Prepaid subscribers represent the overwhelming customer majority for many mobile operators across the world.

Benjamin oghojafor (2012) stated that major challenge facing telecoms business providers in Nigeria is the continuously growing competition and customers' expectation of service quality. Customers are able to choose among multiple service providers based on the level of satisfaction, affordability, and service quality of service providers. Customer demand and competition are forcing firms to cut loose from the traditional customer satisfaction paradigm, to adopt proactive strategies which will assist them to take the lead in the market-place.

Pratompong srinuana, Erik bohlina \& Gary madden (2012) explained about the strategic instruments, such as termination-based price discrimination and calling clubs, which add to consumer switching costs in the Swedish mobile.

W. Bruce Allen, (2012), pointed out the major differences between the united states and India markets in terms of the preponderance of prepaid services in India, the dominance of $2 \mathrm{~g}$ services in India compared to the advancements in $3 \mathrm{~g}$ and $4 \mathrm{~g}$ in the u.s.; the use of wireless handsets that support multiple carriers in India, as compared to the u.s. where services and devices are generally bundled together; and the much higher churn rate in India as consumers switch to lower-cost plans.

Kojo abiw-abaidoo JR (2011), stated that churn affects market share, frustrates effort to achieve projected revenue, dissatisfied customers dent the brand image, increases operational costs as it requires marketing intervention to win-back churners as well as potential churners. Developing the predictive model, the neural 
network was used to calculate the propensity for a customer in the dataset to churn while the decision tree describes the behavior of the churners.

Goran kraljevi'c, sven gotovac (2010), stated the importance of successful model for prediction of potential prepaid churners, in which the most important part is to identify the very set of input variables that are high enough to make the prediction model precise and reliable. Several models have been created and compared on the basis of different data mining methods and algorithms

Rafi kretchmer, (2009), pointed out the reasons of customers spending, especially if they are on a tight budget. This explains the prevalence of prepaid services in emerging economies. In addition, many customers want to ensure they have a choice and are not tied down by a contract to one service provider, (how to promote loyalty with prepaid customers).

Piotr sulikowski, Poland (2008), used a set of potential churn factors on which data can be relatively easily extracted from the operator's databases and analyzed using the SAS. A multi-stage research procedure utilizing such real-world data is proposed. It allows the identification of significant churn factors, the segmentation of customers, and finally the establishing of a rule model of the phenomenon for each customer segment.

Carole manero, France (2008), pointed out retaining customers is one of the most critical challenges in the maturing mobile telecommunications service industry. Customer churn adversely affects mobile telecom operators because they stand to lose a great deal in price premium, decreasing profits levels and a possible loss of referrals from continuing service customers.

Figuring how to deal with churn is turning out to be the key to the survival of telecoms organizations, Angela stainthorpe (2008), explained that, mobile number portability (mnp) implementation is gathering pace across the world. Much of Western Europe and North America is used to the easy freedom subscribers have to move between operators, and many operators in the rest of the world will soon learn first-hand what this freedom will mean for their business. But mnp does not necessarily mean increased churn and increased costs; thorough preparation is central to turning mnp implementation from threat to opportunity.

Shan jin1, Yun meng1, Chunfen fan1, Feng Peng, Qingzhang Chen (2008), pointed out the use data exploration technology to build a predictive model, find out the possible churners and provide personalized service. Compare the performance of different data mining techniques to select appropriate data mining tools.

Lee, h., lee, y and Yoo, d (2000), pointed out that customer satisfaction is influenced by customers' perceptions of quality service quality is an antecedent of the broader concept of customer satisfaction. Satisfaction is the customers' evaluation of services after purchase as opposed to their expectation.

Junxiang Lu (1995), explained about predicting customer churn in the telecommunications industry, applying survival analysis to predict customer churn using data mining techniques.

\subsection{Research Questions}

1. What are the key reasons for churn by the customers selecting specific service providers?

2. How can mobile operators sustain their customer base?

\subsection{Problem Focus}

India has more than 15 mobile operators in a highly competitive, predominantly pre-paid market. About $96 \%$ of all mobile subscribers are constantly transitioning between mobile service providers to realize incrementally lower prices. The monthly churn rate in India averages approximately $6 \%$.reasons for disloyalty varies for different operators as this market is highly competitive. Customer loyalty generally declines and willingness to churn increases as market is subjected to technological changes. Recent churners often switch because of promotional offers from competing providers. Apart from technological reasons, India is overwhelmingly with prepaid market, there is scope for greater disloyalty among subscribers. According to the recent statistics, Indian churn rate has gone up to 14 per cent per month while incremental net adds are at 8-10 million (Note 1). It is accretive for the industry, were customers are running on a treadmill and cost of acquisitions of a new subscriber is leading to huge cash burn. The churn is very high especially in the youth segment. Customer retention is a challenge as churn takes place in the short period of less than 24 months (Note 2).

Globally, India stands first in youth population. According to the recent telecom statistics of 2014 young adults tend to churn in a higher rate when compared with other age category. This is mainly due to their level of expectations and preferences are varying according to the mobile market trend. Hence it is very difficult even to the market giant to cut down churn. The strategy seems clear. India is no longer just a new market for telecom where subscriber acquisition is the key. It is now at the earlier stage of saturation, but one in which rising 
revenues from existing customers is becoming increasingly important for profitability. (Note 3) Mobile operators have to design special campaigning programs to concentrate this segment

Mobile operators are constrained by the customer churn. This is in spite of introducing various new schemes with customer-friendly features which enhance customer benefits. With the cost of operations becoming a challenge, the increasing role of TRAI (telecom regulatory authority of India) enforcing discipline among the operators in terms of rates and regulation on operation, adding complexity to this situation. Each mobile operator need to evolve strategies to arrest churn rate. To manage this situation, operators have to understand and identify factors which influence the customer churn. As is always said the primary task of every business is not only to find new customers, but is to retain the existing customers. Hence, knowledge of churn rate will enable the mobile operators to design and implement strategies to achieve a higher rate of customer retention.

\section{Research Objectives}

1. To ascertain the factors influencing the customer churn with respect to Indian prepaid mobile services.

2. To develop the conceptual model on customer churn to examine the behavioral constructs about the mobile service provider.

\section{Research Methodology}

\subsection{Justification for Study}

Churn rate in Indian mobile industry is alarmingly at a higher rate even though the mobile subscription is subject to tremendous growth. Marketers are designing several schemes and service plans to increase the longevity of the customers in to their network. For this they are allocating huge investments for conducting promotional campaigns and publicity, but it is unfortunate that they could not realize the output in terms of return on investments. At the same time customers are highly choosy based on different attributes of mobile services and they are hopping from operator to operator, since they don't have any commitment in terms of contract with respect to prepaid services. They have scattered needs and switching behavior especially with prepaid segment. That's why the churn growth is increasing substantially in India. Although mobile operators are devoted to improve customer loyalty with their innovative strategies they have not succeeded in arresting the churn rate.

\subsection{Research Design}

The study is pertained with descriptive research method.

\subsubsection{Data Collection}

Primary data and secondary data were collected for conducting this study

\section{Primary data:}

Survey method using structured questionnaire was adopted for collecting the primary data.

\section{Secondary data:}

The secondary data were collected from the earlier research findings, scholarly reports, and telecommunication reports such as TRAI, COAI, Journals, Magazines, and Newspapers etc.

\subsection{Sampling Framework}

Tamilnadu was selected for the study based on the following reasons,

It is second largest in India by prepaid mobile subscription (Note 4) and third largest contributor (as of 2010) to India's GDP (Note 5). Out of 886.3 million prepaid subscribers in India, $10 \%$ are from Tamilnadu (as of December 2013) (Note 6). Leading mobile operators in Tamilnadu are Vodafone Essar, Aircel limited, BSNL, Bharti Airtel, idea, Videocon, reliance CDMA \& GSM, Tata Docomo, CDMA \& GSM, Virgin CDMA \& GSM, MTS. compared to national churn rate, the monthly churn rate in Tamilnadu averages approximately $6.17 \%$

Customers have been selected from ten major cities of Tamilnadu such as Chennai, Madurai, Dindugul, Coimbatore, Trichy, Salem, erode, Vellore, Tirunelveli, Thanjavur based on prepaid subscription and churn rate of 2013 (Note 7)

\subsection{Period of the Study}

- Primary data were collected during 2012 and 2013 for sample survey.

- Secondary data were collected from 2008 onwards. 


\subsection{Sample Method and Size}

Purposive sampling method was followed for selecting the respondents.

1. Prepaid subscribers were identified after enquiring the type of services used with respect to the prepaid mobile operators.

2. Respondents of all age groups were included.

3. Sample size determination:

The data taken for the study is predominantly nominal and ordinal. Bartlett, Kotrlik and Higgins (2001) suggested suitable sample size calculation for such data with very large sample size. For social sciences research alpha level of .05 and the level of acceptable error at $5 \%$ is considered. The population of prepaid subscribers in Tamilnadu obtained from TRAI report 2014 is 88 millions

Sample size determination (when population is known)

$$
\begin{gathered}
n=\frac{z^{2} N \sigma_{p}^{2}}{(N-1)^{2}\left(e^{2}\right)+z^{2} \sigma_{p}^{2}} \\
\text { Z- Confidence level }=2.57(99 \%) \\
\mathrm{N} \text { (total population) }=88000000 \\
\Sigma \mathrm{p}-2 \text { (standard deviation) } \\
\text { E- Level of precision }=0.80(99 \% \text { probability) } \\
\mathrm{N}=\frac{(2.57)^{2} *(88000000) *(2)^{2}}{(88000000-1) *(0.80)^{2}+(2.57)^{2} *(2)^{2}}=413
\end{gathered}
$$

Thus the sample size determined was 413 . However, to increase the reliability of data, sample size chosen was 1102 .

Totally 10 cities were taken in Tamilnadu and 100 samples were collected from each city, except Chennai. In order to have adequate representation of Chennai city, the sample size of 202 were taken based on the strength of prepaid mobile subscription. (Note 8)

\section{Reliability \& Validity}

\subsection{Reliability}

Reliability is the degree to which an assessment tool produces stable and consistent results. Through SPSS 20 package, reliability of questionnaire was tested and cronbach alpha value was found to be 0.94 .

\subsection{Validity}

Internal and external validity were checked with the respective experts to verify the content validity. Hypothesis is backed by questionnaire so that it could be tested and measured. And it is verified with respective literature study to check the face validity.

\section{Pilot Study}

Before finalizing the questionnaire it was subjected to field test with 100 respondents. This helped to fine tune the questionnaire and pilot study was performed in Chennai.

\subsection{Data Processing}

Checked missing values, outliers, skewness close to 0 , kurtosis $(-1$ to +1$)$, z score $(-3.29$ to +3.29$)$ - by plotting in the histogram.

\subsection{Normality}

The majority of the questions are with attitudinal scales. As per the conventional rule of thumb, the categorical scores are converted to continuous scores using $\mathrm{z}$ score transformation in order to perform parametric test (MANOVA). 


\subsection{Variables Overview}

Table 1. List of predictors

\begin{tabular}{ll}
\hline Constructs & Items-measurement of variables(level of satisfaction) \\
\hline Handset details & Number of mobile phones usage(x1) \\
Purchasing decision & Design of the mobile phone(x2) \\
Internet usage & Video(x3) \\
& Type of the data card(x4) \\
& Place of purchase(x5) \\
& Awareness(x6) \\
& Personal use(x7) \\
& Alternative choice due to non-availability(x8) \\
& Tariff(x9) \\
& Changing the brand(x10) \\
& Net speed(x11) \\
Data card & Signal strength(x12) \\
& Good impression on the corporate image(x13) \\
Corporate image & Recharge vouchers(x14) \\
Performance & Tariff rates(x15) \\
& Internet services(x16) \\
Customer relationship & Customer care(x17) \\
management & Time taken for complaint resolution(x18) \\
& Welfare to the society(x19) \\
& Pulsing/timing(x20) \\
Price & Quality of coverage(x21) \\
Service quality & Easiness in subscription(x22) \\
& Recharge process(x23) \\
& Functional product(x24) \\
& Quick customer complaint redressed(x25) \\
& Application process(x26) \\
& Reach of customer services(x27) \\
& Readiness of customer care(x28) \\
& Availability and easiness of services(x29) \\
& Front end services(x30) \\
& Customer services(x31) \\
& Call centers(x32) \\
& Personalization(x33) \\
& \\
\hline
\end{tabular}

The list of predictors are presented in the table 1 and all are measured by the level of customer satisfaction using likert five point scale according to the research objective two, in order to perform data mining, the list of predictors are taken forward for predicting churn using neural networks.

The lists of criteria are presented in the table 2 and all are measured by the level of customer agreement using likert 5 point scale. According to the research objective 1, these variables are subjected to MANOVA for the following reasons.

\section{Research Objective 1}

To identify the factors influencing the customer churn with respect to Indian prepaid mobile services.

\subsection{Statistical Tool: MANOVA}

\section{Principle:}

Multiple analysis of variance (MANOVA) MANOVA is used to test the difference between groups across several dependent variables simultaneously. And it is used to see the main and interaction effects of categorical variables on multiple dependent interval variables. The multivariate formula for $\mathrm{f}$ is based not only on the sum of squares between and within groups, as in ANOVA, but also on the sum of cross products - that is, it takes covariance into account as well as group means and removes type I error. 
Here as per the research objective, MANOVA is applied to find the significant factors inducing customers to churn. Hence the factors influencing the customer churn are taken as fixed factors and prepaid mobile operators are taken as criterions.

Table 2. List of criterions

\begin{tabular}{ll}
\hline Construct & Items-measurement of variables(level of agreement) \\
\hline Churn & Mobile number portability(y1) \\
Network coverage(y2) & Economic in cancelling and entering in to new connection(y3) \\
Compatible to use new handset and accessories of other mobile \\
operator-solving my need(y4) \\
No penalty and no loss in discounts and offers(y5) \\
New products and services are easy to use and economical to \\
access(y6) \\
There is no risk and uncertainty cost involved in switching(y7) \\
Endogenous cost-company itself recommends switching(y8) \\
Easy to search and adopt the facilities involved(y9) \\
Psychologically feeling better in switching(y10) \\
Tariff plan(y11) \\
Billing(y12) \\
Vas services(y13) \\
Quality of service(y14) \\
Customer care services(y15) \\
Offers / discounts/ promotional offers / additional \\
packages(y16) \\
Handset enabled services(y17) \\
Accessibility(y18) \\
Technology(y19) \\
Brand(y20) \\
Preferred applications (SMS,MMS) (y21) \\
Social media applications(y22) \\
Internet facilities(y23) \\
Waiting time(y24) \\
Moral or ethical issues(y25) \\
Free roaming(y26) \\
Regulatory certainty of operations by mobile service \\
provider(y27) \\
Same network as friends and family(y28) \\
Internal switching-my service provider insisted to switch from \\
my prepaid to his postpaid connection(y29) \\
Present mobile operator is having switching provision(y30) \\
\end{tabular}

H0-1: there is no significant relationship between the factors affecting churn and the service providers.

Table 3. Box's test of equality of covariance matrices

\begin{tabular}{cc}
\hline Box's m & $\mathbf{6 2 3 2 . 6 1 4}$ \\
\hline F & 6.205 \\
Df1 & 930 \\
Df2 & 404485.905 \\
Sig. & 1.000 \\
\hline
\end{tabular}

The significance value of 1.000 indicates that the data do not differ significantly from multivariate normal. This means one can proceed with the analysis. 
Table 4. Bartlett's test of Sphericity

\begin{tabular}{cr}
\hline \multicolumn{2}{c}{ Bartlett's test of Sphericity } \\
\hline Likelihood Ratio & .000 \\
Approx. Chi-Square & 35979.93 \\
df & 464 \\
Sig. & .000 \\
\hline
\end{tabular}

This tests the null hypothesis that the correlation matrix is an identity matrix. Since barlett's test is highly significant $(\mathrm{p}<0.001)$, factor analysis is appropriate since the correlation between the items are sufficiently large.

Table 5. Multivariate tests

\begin{tabular}{llccccc}
\hline Effect & \multicolumn{1}{c}{ Value } & F & $\begin{array}{c}\text { Hypothesis } \\
\text { df }\end{array}$ & $\begin{array}{c}\text { Error } \\
\text { df }\end{array}$ & & Sig. \\
\hline Churn & Pillai's trace & .473 & 1.762 & 300.000 & 10640.000 & .000 \\
& & & & & \\
& $\begin{array}{l}\text { Wilks' } \\
\text { lambda }\end{array}$ & .612 & 1.779 & 300.000 & 10060.444 & .000 \\
& $\begin{array}{l}\text { Hotelling's } \\
\text { trace }\end{array}$ & .511 & 1.795 & 300.000 & 10532.000 & .000 \\
& $\begin{array}{l}\text { Roy's largest } \\
\text { root }\end{array}$ & .124 & $4.412^{\mathrm{b}}$ & 30.000 & 1064.000 & .000 \\
\hline
\end{tabular}

The table labelled multivariate tests gives the results of the MANOVA. There are four test statistics (Pillai's trace, Wilks's lambda, Hotelling's trace and Roy's largest root) if the value of significance for this statistic is less than .05 then the groups differ significantly with respect to the criteria.

Table 6. Levene's test of equality of error variances

\begin{tabular}{ll}
\hline \multicolumn{1}{c}{ Factors } & F \\
\hline New products and services are easy to use and economical to access & $2.550^{* *}$ \\
There is no risk and uncertainty cost involved in switching & $2.164^{* *}$ \\
Easy to search and adopt the facilities involved & $2.004^{* *}$ \\
Quality of service & $2.178^{* *}$ \\
Offers / discounts/ promotional offers / additional packages & $2.658^{* *}$ \\
Accessibility & $2.037^{* *}$ \\
Preferred applications (SMS,MMS) & $1.932^{* *}$ \\
Social media applications & $2.848^{* *}$ \\
Internet facilities & $2.264^{* *}$ \\
Free roaming & $1.988^{* *}$ \\
Regulatory certainty of operations by mobile service provider & $1.891^{* *}$ \\
Internal switching-my service provider insisted to switch from my prepaid to his postpaid & $1.950^{* *}$ \\
connection & \\
\hline
\end{tabular}

** 99\% confidence level 
Here, since Levene's test is significant, the data fail the assumption of equal group error variances. In the figure below, Levene's test shows that the assumption of homogeneity of error variances among the groups of "churn factors" is violated for 12 variables listed.

Table 7. Tests of between-subjects effects

\begin{tabular}{|c|c|}
\hline Factors & $\mathbf{F}$ \\
\hline Mobile number portability(y1) & $2.659 * *$ \\
\hline Network coverage(y2) & $1.892 * *$ \\
\hline $\begin{array}{l}\text { Compatible to use new handset and accessories of other } \\
\text { mobile operator-solving my need(y4) }\end{array}$ & $1.916^{* *}$ \\
\hline Easy to search and adopt the facilities involved(y9) & $1.926^{* *}$ \\
\hline quality of service(y14) & $2.415^{* *}$ \\
\hline $\begin{array}{l}\text { Regulatory certainty of operations by mobile service } \\
\text { provider(y27) }\end{array}$ & $1.967 * *$ \\
\hline
\end{tabular}

The output contains the MANOVA summary table [table: 5] for the dependent variables. The row labeled group contains a MANOVA summary table for each of the dependent variables, and important parts of this table are the columns labeled $\mathrm{f}$ and significance, in which the f-ratios for each MANOVA and their significance values are listed based on their interaction effects.

It is clear from the above table, the null hypothesis is rejected. Hence it is proven that there is a significant relationship between mobile number portability, network coverage, compatible to use new handset and accessories, easiness in usage, quality of service and regulatory certainty and the service providers.

Therefore the mobile operators should concentrate on all above factors to devise their loyalty programs and implement the effective customer relationship strategies. It is always easy for the customers to switch the operators by not changing their numbers to utilize more benefits from other operators. Hence the operators should improve their technology on quality of service and network coverage to retain their customer base. The hype of this market is mainly on the arrivals of high-tech mobile phones with all facilities at single touch. The majority of the customers are alpha numeric in nature- ready to take up innovations. Their mind mapping is on mobile phones based operator's service. Hence the operators should be keen on mobile phone technology and compatibility with all versions. They have to provide add on benefits compatible to new versions of mobile phones to retain long tenured customers.

\section{Research Objective 2}

To develop the conceptual model on customer churn to examine the behavioral constructs about the mobile service provider.

\subsection{Modeling Tool: Neural Networks}

\subsubsection{Artificial Neural Network Model}

Neural networks are nonlinear data driven, self-adaptive approach and as powerful tool for modeling. It imitates human brain and can process complex data. Multilayer perceptron on (mlp) and radial basis function (RBF) networks are supervised in the sense that the model predicted results can be compared against known values of the target variables. The parameters of the networks should be found by applying optimization methods. The optimization is done with respect to the approximation error measure. SPSS neural networks option A allows fitting mlp and RBF networks and saving the resulting models for scoring. Multilayer perceptron networks are used when parameters are non - linear and radial basis function networks are used if the parameters are linear. The procedure adopted in this study was multilayer perceptron network since the parameters used for modeling are non-linear. 


\subsubsection{Multilayer Perceptron Network Model}

The multilayer perceptron procedure produces a predictive model for one or more dependent (target) variables based on the values of the predictor variables. The dependent variables can be nominal, ordinal or scale. Multilayer perceptron procedure can find more complex relationships. If MLP network allows a second hidden layer, each unit of the second hidden layer is a function of the units in the first hidden layer, and each response is a function of the units in the second hidden layer. In this study two hidden layers for modeling using multilayer perceptron approach

\subsection{Model Output Using Testing Sample}

The factors from the output of MANOVA are fed as the factors for developing the base model. The factors of churn are taken as dependent factors, customer satisfaction are taken as independent factors and cities are taken as covariates.

The estimated results of the base model are given in the following tables.

Table 8 . Case processing summary

\begin{tabular}{lcc}
\hline Sample & N & Percent \\
\hline Training & 773 & $70.3 \%$ \\
Testing & 327 & $29.7 \%$ \\
Valid & 1100 & \\
Excluded & 2 & \\
Total & 1102 & \\
\hline
\end{tabular}

The case processing summary given in the above table shows that 773 samples were assigned to the training sample, 327 to the testing sample and two of the cases were excluded from the analysis.

The network information in above table displays information about the neural network and is useful for ensuring that the specifications are correct. The number of units in the input layer is the number of covariates plus the total number of factor levels. One hidden layer was requested and the procedure has chosen 12 units in the hidden layer. A separate output unit was created for the scale- dependent variable. They are rescaled by the standardized method, which requires the use of the hyperbolic tangent activation function for the output layer. Sum-of-squares error was reported because the dependent variables are scaled.

The model summary in the table 10 displays information about the results of training and applying the final network to the holdout sample. Sum-of-squares error was displayed because the output layer has scale dependent variables. This was the error function that the network tries to minimize during training. Note that the sums of squares and all following error values are computed for the rescaled values of the dependent variables. The relative error for each scale-dependent variable was the ratio of the sum-of squares error for the dependent variable to the sum-of-squares error for the "null" model, in which the mean value of the dependent variable is used as the predicted value for each case. The relative errors are fairly constant across the training, testing, and hold out samples, which gives confidence that the model is not over-trained and that the error in future cases, scored by the network will be close to the error reported in this table. The estimation algorithm stopped because the error did not decrease after a step in the algorithm.

The importance of independent variables is listed as per the simulated pattern of brain functioning of the customers using the synoptic weights of each neuron. Hence the customers are giving importance to the mobile phone usage and purchase of new phones with advanced technology and designs. They are giving priority to internet services and personalization -e services.in connection to this they expect wider coverage of network with high quality and signal strengths. They seek good image of the corporate and awareness over various schemes and services. As they are main churning factors for the customer, the mobile operators should focus on compatible mobile phone based services. They can revamp their conventional mode of networking and avail the technology transfer to implement robust technology in network coverage and signal strength. Since majority of the customers are using data services, they can increase the options in schemes. 
Table 9. Network information

\begin{tabular}{|c|c|c|}
\hline Layers & Particulars & Factors \\
\hline \multirow[t]{36}{*}{ Input layers } & Independent variables & Number of mobile phones usage(x1) \\
\hline & & Design of the mobile phone(x2) \\
\hline & & $\operatorname{Video}(\mathrm{x} 3)$ \\
\hline & & Type of the data card(x4) \\
\hline & & Place of purchase $(x 5)$ \\
\hline & & Awareness(x6) \\
\hline & & Personal use(x7) \\
\hline & & Alternative choice due to non-availability(x8) \\
\hline & & Tariff(x9) \\
\hline & & Changing the brand(x10) \\
\hline & & Net speed(x11) \\
\hline & & Signal strength $(\mathrm{x} 12)$ \\
\hline & & Good impression on the corporate image(x13) \\
\hline & & Recharge vouchers(x14) \\
\hline & & Tariff rates $(\mathrm{x} 15)$ \\
\hline & & Internet services(x16) \\
\hline & & Customer care(x17) \\
\hline & & Time taken for complaint resolution(x18) \\
\hline & & Welfare to the society $(\mathrm{x} 19)$ \\
\hline & & Pulsing/timing(x20) \\
\hline & & Quality of coverage(x21) \\
\hline & & Easiness in subscription(x22) \\
\hline & & Recharge process(x23) \\
\hline & & Functional product(x24) \\
\hline & & Quick customer complaint redressed(x25) \\
\hline & & Application process(x26) \\
\hline & & Reach of customer services(x27) \\
\hline & & Readiness of customer care $(\mathrm{x} 28)$ \\
\hline & & Availability and easiness of services(x29) \\
\hline & & Front end services(x30) \\
\hline & & Customer services(x31) \\
\hline & & Call centers(x32) \\
\hline & & Personalization(x33) \\
\hline & Covariate & Cities \\
\hline & Number of units & 186 \\
\hline & Rescaling method for covariates & Standardized \\
\hline \multirow[t]{3}{*}{ Hidden layers } & Number of hidden layers & 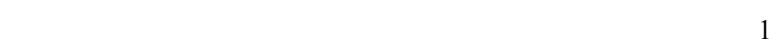 \\
\hline & Number of units in hidden layer 1 & 12 \\
\hline & Activation function & Hyperbolic tangent \\
\hline \multirow[t]{10}{*}{ Output layers } & Dependent variables & Mobile number portability(y1) \\
\hline & & Network coverage(y2) \\
\hline & & $\begin{array}{l}\text { Compatible to use new handset and accessories of other mobile } \\
\text { operator-solving my need(y4) }\end{array}$ \\
\hline & & Easy to search and adopt the facilities involved(y9) \\
\hline & & quality of service(y14) \\
\hline & & Regulatory certainty of operations by mobile service provider(y27) \\
\hline & Number of units & 6 \\
\hline & Rescaling method for scale dependents & Standardized \\
\hline & Activation function & Identity \\
\hline & Error function & Sum of squares \\
\hline
\end{tabular}


Table 10. Model summary

\begin{tabular}{lc}
\hline & Model summary \\
\hline Training sum of squares error & 30.14 \\
Average overall relative error & .020 \\
Stopping rule used & 1 consecutive step with no decrease in error \\
Training time & $0: 00: 04.53$ \\
Testing sum of squares error & 10.17 \\
Average overall relative error & .034 \\
\hline
\end{tabular}

Table 11. Independent variable importance

\begin{tabular}{lcc}
\hline \multicolumn{1}{c}{ Factors } & Importance & $\begin{array}{c}\text { Normalized } \\
\text { importance }\end{array}$ \\
\hline Number of mobile phones usage(x1) & .075 & $100.0 \%$ \\
Design of the mobile phone(x2) & .050 & $66.2 \%$ \\
Video(x3) & .018 & $23.5 \%$ \\
Type of the data card(x4) & .025 & $32.5 \%$ \\
Place of purchase(x5) & .041 & $54.7 \%$ \\
Awareness(x6) & .045 & $59.8 \%$ \\
Personal use(x7) & .040 & $53.1 \%$ \\
Alternative choice due to non-availability(x8) & .027 & $36.3 \%$ \\
Tariff(x9) & .028 & $36.6 \%$ \\
Changing the brand(x10) & .033 & $43.7 \%$ \\
Net speed(x11) & .035 & $47.1 \%$ \\
Signal strength(x12) & .049 & $64.6 \%$ \\
Good impression on the corporate image(x13) & .021 & $28.1 \%$ \\
Recharge vouchers(x14) & .029 & $39.0 \%$ \\
Tariff rates(x15) & .021 & $27.2 \%$ \\
Internet services(x16) & .039 & $52.1 \%$ \\
Customer care(x17) & .021 & $28.3 \%$ \\
Time taken for complaint resolution(x18) & .020 & $27.1 \%$ \\
Welfare to the society(x19) & .026 & $34.4 \%$ \\
Pulsing/timing(x20) & .028 & $37.7 \%$ \\
Quality of coverage(x21) & .058 & $77.0 \%$ \\
Easiness in subscription(x22) & .027 & $36.4 \%$ \\
Recharge process(x23) & .026 & $34.8 \%$ \\
Functional product(x24) & .021 & $27.6 \%$ \\
Quick customer complaint redressed(x25) & .036 & $47.5 \%$ \\
Application process(x26) & .023 & $30.0 \%$ \\
Reach of customer services(x27) & .019 & $25.5 \%$ \\
Readiness of customer care(x28) & .027 & $35.4 \%$ \\
Availability and easiness of services(x29) & .025 & $32.6 \%$ \\
Front end services(x30) & .036 & $47.5 \%$ \\
Customer services(x31) & .025 & $33.7 \%$ \\
Call centres(x32) & .004 & $5.9 \%$ \\
Personalization(x33) & .075 & $66.0 \%$ \\
District & .050 & \\
\hline & & \\
& &
\end{tabular}

Mobile operators can also allocate budget in raising their level of awareness about their data schemes through rigorous market campaigning. Even though mobile operators are highly competitive in making price wars, they failed to fill the need gaps of the customers. From the above analysis customers are highly confined to internet usage. Bharti Airtel, reliance and other players are very conscious in reducing price tariffs especially in voice calls and not very much on data packages. Hence they have to classify and devise the need based data schemes. 


\section{Conclusions and Recommendations}

Mobile operators have to develop the policies by devising the strategies in the following areas:

1. Network integration with banks:-by integrating with banks mobile operators can reduce their operational cost and enhance the add-on benefits to the customers like recharging, activation, billing etc.

\section{Campaign management:}

By designing powerful awareness programs through road shows, innovative mass promotion with various schemes on data and voice services, the campaign management can aim to achieve desired customer retention.

3. Mobile analytics: - based on the mobile analytics, networking should be devised with high technology of wide coverage having superior signal strength to reduce churn

4. Participative management: Result oriented Customer participative initiatives are to be developed to design various marketing elements.

5. Social media marketing: Exploiting the reach of social media marketing in the service providers should build awareness and route their promotional options.

6. Affiliate marketing: online advertisements, online contests, multilevel marketing can be done through internet services like launching targeted real time promotions-free calls, SMS, MMS-closed user group, announcing yearly, monthly contracts with special allowance, monthly free minutes, mobile wallet services, e community centers, buzz marketing e procedures, banking, subsidized data cards, e scoring-mobile wallets etc. Through this churn can be minimized since majority of the customers are internet users.

7. A mobile banking capability would be one that goes beyond making and receiving payments, enabling the end user to manage on-demand savings balances and potentially use a broader range of products that allow for safe storage of value, as well as credit and insurance. Arpu, M\&A, regulation, licensing and technology coverage. Hence Indian mobile operators have to update information through this interface.

8. Concentrated strategy need to be employed for developing hybrid models that are compatible to smart phones, tablets, dongles, enhancing e procedures, differentiate offerings-data quantities, speed, services and cost, installing high tech carriers, creating cross line of bundle service offerings, providing subsidized handsets and rapid configuration of new prepaid services.

9. Price differentiation strategies have to be devised for both voice and data services like monthly quota services, bundled prepaid lines with auto mated recall services, schemes on rate cutters, SMS, MMS, roaming, data schemes etc.

10. Youth marketing strategies are needed to attract this segment by providing compatible services for smart phones, tablets, dongles, conducting campaigns \& event marketing, developing concept /message marketing, offering special allowances-sms, mms, free ring tones, caller tones, pocket data services.

11. Regio-centric strategies-strategies to be designed based on every city or regions to capture the needs of the customers like networking of physical retail outlets, expanding mobile banking capability, applying the concept of collaborative marketing-cross \& up selling

\section{Summary}

Research is all about determinants of customer churn behavior focusing on prepaid mobile services of Tamilnadu, is a process by which data from customer behavior is aggregated and analyzed to gain customer mind map. Reasons for churn were found to be issues related to technology based services, network coverage, net speed, complaint resolution. Based on this model was designed and strategies were devised to seize out the churn

\section{Usefulness of Study}

The major outcome of this study highlights the importance about the customization of mobile phones and their designs in predicting churn. It also mentions the significance of social media and affiliate marketing to control churn. Simulated mode of customer's mind mapping on various buying attributes revitalizes the mobile operators to design the retention strategies like online catalogues, spot exchanges of mobile phones, $\mathrm{B} 2 \mathrm{C}$ auction sites and developing customer community center

\section{References}

Ahmad, R., \& Buttle, F. (2003). Customer Retention Management: A Reflection of Theory and Practice. Journal of Marketing Intelligence and Planning, 20(3), 149-161. http://dx.doi.org/10.1108/02634500210428003 
Ahn, J., Han, S., \& Lee, Y. (2006). Customer churn analysis: Churn determinants and mediation effects of partial defection in the Korean mobile telecommunications service industry. Telecommunications Policy, 30(10-11), 552-568. http://dx.doi.org/10.1016/j.telpol.2006.09.006

Bateson, J. E. G., \& Hoffman, K. D. (1999). Managing Services Marketing: Text and Readings (4th ed.). Orlando, FL: Dryden Press.

Baurdeau, A., Liebenau, J., \& Savin, B. (2005). A New View of Scale and Scope in the Telecommunications Industry; Implications for Competition and Innovation. International Journal of Digital Economics, 60(4), 85-103.

Berson, A., Smith, S., \& Thearling, K. (2002). Building Data Mining Applications for CRM. New York: McGrawHill.

Bolton, R. N., Kannan, P. K., \& Bramlett, M. D. (2000). Implications of Loyalty Program Membership and Service Experiences for Customer Retention and Value. Journal of the Academy of Marketing Science, 28, 95-108. http://dx.doi.org/10.1177/0092070300281009

Bose, I., \& Chen, X. (2009). Exploring business opportunities from mobile services data of customers: An inter-cluster analysis approach. Electronic Commerce Research and Applications, 9(3), 197-208. http://dx.doi.org/10.1016/j.elerap.2009.07.006

Boulding, W., Kalra, A., Staelin, R., \& Zeithaml, V. A. (1993). A Dynamic Process Model of Service Quality: From Expectations to Behavioral Intentions. Journal of Marketing Research, 30, 7-27. http://dx.doi.org/10.2307/3172510

Brown, L. (2007). What your customers really want: 7 Qualities of Customer Care. Journal of American Salesman, 52(5), 12-15.

Chow, S, \& Holden, R. (1997). Toward an Understanding of Loyalty: The Moderating Role of Trust. Journal of Managerial Issues, 9(3), 275-298.

Coussement, K., \& Van den Poel, D. (2008). Churn prediction in subscription services: An application of support vector machines while comparing two parameter-selection techniques. Expert Systems with Application, 34(1), 313-327. http://dx.doi.org/10.1016/j.eswa.2006.09.038

DeSouza, G. (1992). Designing a Customer Retention Plan. Journal of Business Strategy, 24-25. http://dx.doi.org/10.1108/eb039477

Donio, J., Massari, P., \& Passiante, G. (2006).Customer Satisfaction and Loyalty in a Digital Environment: An Empirical Test. Journal of Consumer Marketing, 23(7), 445-457. http://dx.doi.org/10.1108/ 07363760610712993

Drucker, P. F. (1973). Management: Tasks, Responsibilities, Practices, Harper and Row. New York.

Edwards, J. (2007). Get It Together with Collaborative CRM Inside CRM. Tippit.

Etzel, W., \& Stanton. (2004). Marketing (13th ed.). New Delhi: Tata McGraw Hill.

Fildes, R. (2002). Telecommunications demand - A review. International Journal of Forecasting, 18, 489-522. http://dx.doi.org/10.1016/S0169-2070(02)00064-X

Gefen, D. (2002). Customer loyalty in e-commerce. Journal of Association for Information Systems, (3), 27-51

Geppert, C. (2002). Customer Churn Management: Retaining High-Margin Customers with Customer Relationship Management Techniques. KPMG \& Associates

Ghauri, P. (Ed.). (1999). Advances in International Marketing and Purchasing: From Mass Marketing to Relationships and Networks. Greenwich, CT: JAI Press.

Grönroos, C. (2000). Service Management and Marketing: A Customer Relationship Management Approach. New York, NY: Wiley.

Hadden, J., Tiwari, A., Roy, R., \& Ruta, D. (2007). Computer assisted customer churn management: State-of-the- art and future trends. Computers and Operations Research, 34(10), 2902- 2917. http://dx.doi.org/10.1016/j.cor.2005.11.007

Harris, L., O'Malley, L., \& Patterson, M. (2003). Professional Interaction: Exploring the Concept of Attraction. Marketing Theory, 3(1), 9-36. http://dx.doi.org/10.1177/1470593103003001002 
Hung, S., Yen, D., \& Wang, H. (2006). Applying data mining to telecom churn management. Expert Systems with Applications, 31(3), 515-524. http://dx.doi.org/10.1016/j.eswa.2005.09.080

Hutt, M. D., \& Thomas W. S. (2004). Business Marketing Management: A Strategic View of Industrial and Organizational Markets (8th ed.). Mason, OH: South-Western.

Hwang, H., Jung, T., \& Suh, E. (2004). An LTV model and customer segmentation based on customer value: A case study on the wireless telecommunication industry. Expert Systems with Applications, 26, 181188. http://dx.doi.org/10.1016/S0957-4174(03)00133-7

Johnson, W. C., \& Sirikit, A. (2002). Service Quality in the Thai Telecommunication Industry: A Tool for Achieving a Sustainable Competitive Advantage. Mgt. Decision, 40(7). http://dx.doi.org/10.1108/ 00251740210438526

Kobsa, A. (2002). Personalized hypermedia and international privacy communications of the ACM, 45, 64-67.

Kotler, et al. (2002). Understanding the relationships among brands, customers and resellers. Journal of the Academy of Marketing Science, 28(1), 17-23.

Kotler, P. (2007). Marketing Management. Analysis, Planning, Implementation, and Control (9th ed.). Englewood Cliffs, NJ: Prentice-Hall International.

Kotler, P., \& Keller, K. L. (2006). Marketing Management (12th ed.). Prentice Hall, Pearson

Lawson-Body, A., \& Limayem, M. (2001). Business-to-Business Electronic Commerce: Impact of web site characteristics on Relationship Marketing Efficiency. Revue des Sciences de Gestion, (5-6), 113-158.

Lejeune, M. A. (2001). Measuring the impact of data mining on churn management. Internet Research: Electronic Networking Applications and Policy, 11(5), 375-387. http://dx.doi.org/10.1108/ 10662240110410183

Li, T., \& Ruan, D. (2007). An extended process model of knowledge discovery in databases. Journal of Enterprise Information Management, 20(2), 169-177. http://dx.doi.org/10.1108/17410390710725751

Ngai, E., Xiu, L., \& Chau, D. (2009). Application of data mining techniques in customer relationship management: A literature review and classification. Expert Systems with Applications, 36, 2592-2602. http://dx.doi.org/10.1016/j.eswa.2008.02.021

Owczarczuk, M. (2010). Churn models for prepaid customers in the cellular telecommunication industry using large data marts. Expert Systems with Applications, 37(6), 4710-4712. http://dx.doi.org/10.1016/j.eswa. 2009.11.083

Parasuraman, A., Zeithaml, V. A., \& Berry, L. L. (1994). Reassessment of Expectations as a Comparison Standard in Measuring Service Quality: Implications for future research. Journal of Marketing, 58, 111-124. http://dx.doi.org/10.1016/j.eswa.2009.11.083

Payne, A. (1994). Relationship marketing making the customer count. Managing Service Quality, 4(6), 29-31. http://dx.doi.org/10.1108/EUM0000000003939

Peppard, J., \& Rylander, A. (2006). From Value Chain to Value Network: Insights for Mobile Operators. European Management Journal, 24(2-3), 128-141. http://dx.doi.org/10.1016/j.emj.2006.03.003

Perreault, W. D. Jr., \& McCarthy, E. J. (2002). Basic Marketing. Boston: McGraw-Hill/Irwin.

Reichheld, F. F. (1996). The Loyalty Effect: The Hidden Force behind Growth, Profits and Lasting Value. Boston MA: Harvard Business School Press.

Reinartz, W. J., \& Kumar, V. (2003). The Impact of Customer Relationship Characteristics on Profitable Lifetime Duration. Journal of Marketing, 67(1), 77-99. http://dx.doi.org/10.1509/jmkg.67.1.77.18589

Rigby, D. K., Reichheld, F. F., \& Schefter, P. (2002). Avoid the four perils of CRM. Harvard Business Review, 80(2), 101-109.

Rowley, J., \& Dawes, J. (2000). Disloyalty: A closer look at non-loyals. Journal of Consumer Marketing, 17(6), 538-549. http://dx.doi.org/10.1108/07363760010349948

Rud, O. P. (2001). Data Mining Cookbook. New York: John Wiley \& Sons.

Rust, R., \& Zahorik, A. (1993). Customer Satisfaction, Customer Retention, and Market share. Journal of Retailing, 69, 193-215. http://dx.doi.org/10.1016/0022-4359(93)90003-2 
Rygielski, C., Wang, J., \& Yen, D. (2002). Data mining techniques for customer relationship management Technology in Society, 24(4), 483-502. http://dx.doi.org/10.1016/S0160-791X(02)00038-6

Şimşek Gürsoy, U. T. (2010). Customer churn analysis in telecommunication sector. Istanbul University Journal of the School of Business Administration, 39(1), 35-49.

Sohn, S., \& Kim, Y. (2008). Searching customer patterns of mobile service using clustering and quantitative association rule. Expert Systems with Applications, 34(2), 1070-1077. http://dx.doi.org/10.1016/ j.eswa.2006.12.001

Song, G., Yang, D., Wu, L., Wang, T., \& Tang, S. (2006). A mixed process neural network and its application to churn prediction in mobile communications. In Proceedings of the Sixth IEEE International Conference on Data Mining Workshops (ICDM Workshops) (pp. 798-802). http://dx.doi.org/10.1109/ICDMW.2006.12

Szeinbach, S. L., Barnes, J. H., \& Garner, D. D. (1997). Use of pharmaceutical manufacturers' value-added services to build customer loyalty. Journal of Business Research, 40(3), 229-236. http://dx.doi.org/10.1016/ S0148-2963(96)00239-1

Thomassey, S., \& Fiordaliso, A. (2006). A hybrid sales forecasting system based on clustering and decision trees. Decision Support Systems, 42(1), 408-421. http://dx.doi.org/10.1016/j.dss.2005.01.008

Wei, C., \& Chiu, I. (2002). Turning telecommunications call details to churn prediction: A data mining approach. Expert Systems with Applications, 23(2), 103-112. http://dx.doi.org/10.1016/S0957-4174(02)00030-1

Wilson, T. D. (1995). An integrated model of buyer-seller. Journal of Academy of Marketing Science, 23(4), 335-345. http://dx.doi.org/10.1177/009207039502300414

Zeithaml, V. A., \& Bitner, M. J. (2000). Services Marketing: Integrating Customer Focus across the Firm (2nd ed.). New York, NY: McGraw Hill.

\section{Notes}

Note 1. http://www.rediff.com/business/slide-show/slide-show-1-is-the-telecom-tariff-party-over-in-india/20110 729.htm\#10

Note 2. http://www.exchange4media.com/e4m/news/printpage.asp?section_id=4\&news_id=10961\&tag=5595

Note 3. http://www.rediff.com/business/slide-show/slide-show-1-is-the-telecom-tariff-party-over-in-india/20110 729.htm\#10

Note 4. http://www.gsmamobileeconomy.com/GSMA\%20Mobile\%20Economy\%202013.pdf

Note 5. http://www.slideshare.net/UttamSatapathy/a-study-of-tamilnadus-economy-and-its-contribution-to-ind ias-gdp

Note 6. http://trace.bharatiyamobile.com/Mobile-Subscriber-Statistical-Data.php

Note 7. http://www.trai.gov.in/

Note 8 . http://www.exchange4media.com/e4m/news/printpage.asp?section_id=4\&news_id=10961\&tag=5595

\section{Copyrights}

Copyright for this article is retained by the author(s), with first publication rights granted to the journal.

This is an open-access article distributed under the terms and conditions of the Creative Commons Attribution license (http://creativecommons.org/licenses/by/3.0/). 